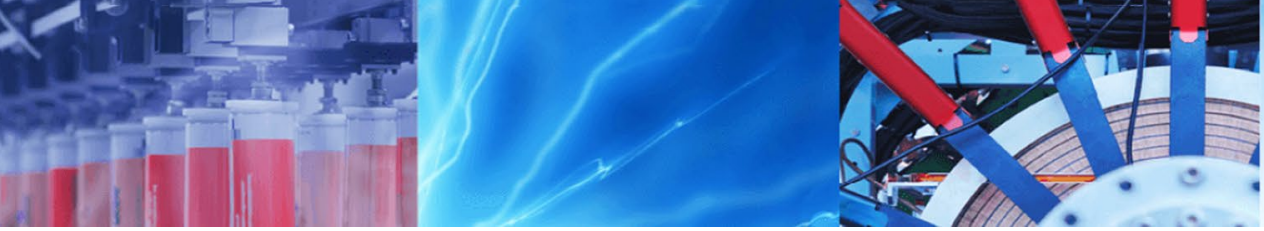

Research Article

\title{
Characterization of lightweight cement concrete with partial replacement of coconut shell fine aggregate
}

\author{
Sunday U. Azunna ${ }^{1} \cdot$ Farah N. A. A. Aziz ${ }^{1}$ Pang M. Cun ${ }^{1} \cdot$ Mohamed M. O. Elhibir ${ }^{1}$
}

(c) Springer Nature Switzerland AG 2019

\begin{abstract}
Nowadays, the natural material as agriculture waste in concrete has been long discussed. Coconut shell is a major agricultural waste that is readily available and can be easily assessed in many countries that are tropical. Coconut shell properties and properties of coconut shell concrete were thoroughly examined and the application as a construction material was evaluated. The linchpin of this study was on the mechanical and physical performance of concrete properties incorporated with coconut shell as a partial replacement for fine aggregate. Concrete incorporated with 10\%, 20\% and $30 \%$ volume fraction replacements for fine aggregate was designed for target strength of $35 \mathrm{MPa}$ to note percentage replacement effects on the structural properties and behavior of the concrete. In total, the compressive and flexural strengths for 72 cubes samples were evaluated in addition to the rate at which cube samples absorbed water. The data obtained were analyzed and discussed. The replacement of coconut shell in volume fractions as fine aggregate in concrete lead to decrease in density, compressive strength and flexural strength with corresponding increase in the absorption properties of concrete as the coconut shell replacement increased. The financial requirement for concrete production decreased as the replacement of coconut shell increased.
\end{abstract}

Keywords Coconut shell · Lightweight aggregate $\cdot$ Lightweight concrete $\cdot$ Compressive strength $\cdot$ Mechanical properties

\section{Introduction}

Natural resources of the world radically diminish as a result of the increasing clamor of naturally occurring aggregates for the field of construction. This have had negative effect on the green nature of the environment and catalyzed the studies and search for viable development by employing other agricultural wastes in the construction sector. Research have shown that aggregates of lightweight produced from the waste of industries such as ground granulated blast furnance slag (GGBS) and fly ash have led to sustainable materials. However, as a result of inadequate knowledge, lack of production techniques and facilities a lot of under-developed nations are yet to make judicious use of these materials. It has been satisfied in developed countries that reduction of structural weight as a result of the use of lightweight aggregates in producing concrete positively propels both the strength and economical growth [1]. The use of natural aggregates in 2006 was nearly $\mathbf{2 7 5}$ million tonnes which is much higher than the 110 million tonnes that was recorded in 1960 in the United Kingdom [2]. United States alone records an aggregate production of 2 billion tonnes annually and in 2020 this figure is estimated to escalate to more than 2.5 billion tonnes [2]. Such substantial demands draw attention and conservation of natural aggregates, which are a matter of heavy concern. Since the concrete volume constitutes of $60-80 \%$ aggregates, effective and adequate use of agricultural waste contributes to energy saving, preservation of natural resources and reduction of the cost of building

Sunday U. Azunna, usazunna@gmail.com; usazunna@yahoo.co.uk| ${ }^{1}$ Housing Research Center, Department of Civil Engineering, Faculty of Engineering, Universiti Putra Malaysia (UPM), 43400 Serdang, Selangor, Malaysia.

SN Applied Sciences (2019) 1:649 | https://doi.org/10.1007/s42452-019-0629-7

Received: 20 January 2019 / Accepted: 16 May 2019 / Published online: 29 May 2019 
materials. In addition, to boost sustainable material in the construction industry and reduce the adverse environmental impact of concrete, wastes from natural resources are introduced as materials for concrete making a substitute solution. Agricultural wastes generated in many tropical countries are in very large amount and improper disposal of these agricultural wastes causes a lot of environmental problems [3]. Some examples of agriculture wastes deposits are coconut shell, oil palm shell, rice husk and corn cob, out of which coconut shell stands out as the most auspicious agro waste for possible replacement of aggregate in concrete production [4].

Different types of waste materials such as cockle shell [5], periwinkle shell [6], date seed [7], rubber seed [8], corn cob [9],coconut shell [2], oil palm shell have partially or fully been used to surrogate fine or coarse aggregate in producing lightweight concrete and their properties evaluated in every investigation [10].

Pinto et al. [9] experimented on corn cob as a lightweight aggregate for non-structural purpose. Expanded shale concrete exhibited density and coefficient of thermal expansion of about $34 \%$ and $27 \%$ respectively higher than that concrete incorporated with corn cob. This shows that corn cob lightweight concrete performs better than concrete with partial aggregate replacement by expanded shale [9]. Rice husk was used in its natural state as a replacement for fine and coarse aggregate in concrete. It was discovered that rice husks could be employed as a structural lightweight material or insulating material. Rice husk has been proven successful for use by several researchers as it possesses the potential to solve the problem of negative environment and economic impact of constant usage of naturally occurring aggregate in concrete production [11]. In recent times, high strength lightweight concrete was produced with oil palm shell showing a compressive strength ranging between 42 and $53 \mathrm{MPa}$ [12-14]. Major observations was that crushed OPS, OPS coarse aggregates of smaller sizes, low water to cement ratio and the incorporation of limestone powder in the concrete mixture as filler are key factors to producing an oil palm concrete of high strength [12].

Many researchers have studied the effect of coconut shell on concrete for the mechanical, chemical, physical and durability properties $[2,15,16]$. The eastern part of southern Asia is regarded as the area where coconut shell originated from and is said to be available in more than 93 nations [15]. Malaysia alone has a coconut shell production of 577,000 metric tonnes and about 114, 000 hectares of coconut plantation in peninsular Malaysia [17]. After removing the coconut, the shells are normally disposed as waste. Large numbers of disposed coconut shells are yet to be used for any commercial purpose; hence incorporating it in concrete as a construction material with respect to other lightweight aggregates is an awesome topic to further look into. The said coconut shell can be grinded and adopted as a fine aggregate in producing lightweight concrete. Provided the minimum required concrete strength can be achieved coconut shells can be used for construction purposes in rural areas where they are readily available likewise in locations where conventional aggregates are very expensive.

In this study, coconut shell concrete will be studied for the mechanical properties namely; compressive and flexural strengths and the absorption of water for different volume fraction of coconut shell aggregate in concrete have been measured to assess how suitable it is as a lightweight aggregate. The cost between coconut shell and sand as fine aggregate in concrete is also studied to analyze and compare the suitability from an economical point of view.

\section{Experimental programme}

This contains a description of the material properties, concrete mixture, design method and experimental tests.

\subsection{Materials}

The materials used for this research are Ordinary Portland cement (OPC), coarse aggregate, fine aggregate (sand) and coconut shell aggregate as raw materials.

\subsection{Cement}

Ordinary Portland Cement was used for this research as it meets the standard stipulated in BS EN 197-1 [18]—M32.5 with respect to EN 197-1 [18], composition, specification and conformity criteria for a common cement.

\subsection{Coarse aggregate}

Maximum aggregate size of $20 \mathrm{~mm}$ crushed type of coarse aggregates obtained from the concrete laboratory of Civil Engineering Department, Universiti Putra Malaysia was used for the research. Aggregates were dry and free of impurities before been used for concrete production ASTM C136 [19]. In accordance to ASTM C33 [20], the dry coarse aggregates were well graded by laboratory sieving. Aggregates with specific gravity of 2.70 were used in saturated surface dry (SSD) to prevent absorption during mixing. Table 1 and Fig. 1 show the grading of coarse aggregate and grading curve for coarse aggregate respectively. 
Table 1 Grading of coarse aggregates

\begin{tabular}{lllc}
\hline Sieve size & $\begin{array}{l}\text { Medium grad- } \\
\text { ing limits (\%) }\end{array}$ & $\begin{array}{l}\text { Percentage } \\
\text { passing (\%) }\end{array}$ & $\begin{array}{l}\text { Percentage } \\
\text { retained (\%) }\end{array}$ \\
\hline $25 \mathrm{~mm}$ (1 in) & 100 & 100 & 0 \\
$19 \mathrm{~mm}$ (0.75 in) & $90-100$ & 100 & 0 \\
$12.5 \mathrm{~mm}(0.5 \mathrm{in})$ & $40-80$ & 70 & 30 \\
$9.5 \mathrm{~mm}$ (0.375 in) & $20-55$ & 45 & 25 \\
$4.75 \mathrm{~mm}$ (No. 4) & $0-10$ & 0 & 40 \\
Pan & 0 & 0 & 5 \\
Total & - & - & 100 \\
\hline
\end{tabular}



Fig. 1 Grading curve for coarse aggregate

\subsection{Fine aggregate}

Fine aggregates passing through $4.75 \mathrm{~mm}$ sieve and settling on $150 \mu \mathrm{m}$ sieve obtained from the concrete laboratory of Civil Engineering Department, Universiti Putra Malaysia were used for the research. Aggregates were dry and free of impurities before been used for concrete production ASTM C136 [19]. Aggregates with specific gravity of 2.64 were used in saturated surface dry (SSD) to prevent absorption during mixing. Table 2 and Fig. 2 shows the grading of fine aggregate and grading curve for fine aggregate respectively.

\subsection{Coconut shell aggregate (CSA)}

Coconut shells were obtained from a local market and allowed to dry under the sun for a period of half a month before being crushed. The crushed edges were rough and spiky and the lengths were restricted to a maximum of 1.18 to $4.75 \mathrm{~mm}$. Figure 3 shows the coconut shell fine aggregates.
Table 2 Grading of fine aggregate

\begin{tabular}{lllc}
\hline Sieve size & $\begin{array}{l}\text { Medium grad- } \\
\text { ing limits (\%) }\end{array}$ & $\begin{array}{l}\text { Percentage } \\
\text { passing (\%) }\end{array}$ & $\begin{array}{l}\text { Percentage } \\
\text { retained (\%) }\end{array}$ \\
\hline $9.5 \mathrm{~mm}$ (3/8 in) & 100 & 100 & 0 \\
$4.75 \mathrm{~mm}$ (No. 4) & $95-100$ & 100 & 0 \\
$2.36 \mathrm{~mm}$ (No. 8) & $80-100$ & 80 & 20 \\
$1.18 \mathrm{~mm}$ (No. 60 & $50-85$ & 55 & 25 \\
$600 \mu \mathrm{m}$ (No. 30) & $25-60$ & 35 & 20 \\
$300 \mu \mathrm{m}$ (No. 50) & $10-30$ & 20 & 15 \\
$150 \mu \mathrm{m}$ (No. 100) & $02-10$ & 3 & 17 \\
Pan & - & 0 & 3 \\
Total & - & - & 100 \\
\hline
\end{tabular}



Fig. 2 Grading curve for fine aggregate

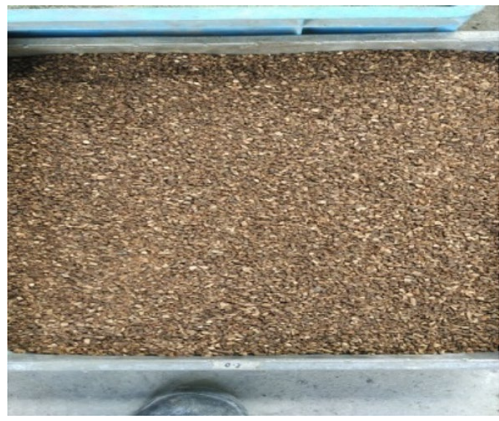

Fig. 3 Crushed coconut shell aggregates

The coconut shells had fairly smooth concave and rough convex faces. CS aggregates have a relatively high water absorption value nearly $6.71 \%$, compared to the conventional fine aggregate (3\%). Table 3 shows the physical properties of the coconut shell. 
Table 3 Physical properties of coconut shell

\subsection{Water}

Clean tap water and constant water cement ratio of 0.54 was used for manufacture of the concrete.

\subsection{Curing condition}

Concrete cubes were immersing into water after $24 \mathrm{~h}$ of casting and tested for strength at ages of 7, 14 and 28 days. It was observed that when concrete cubes are cured for a long period of the incidence cracking is reduced [15].

\subsection{Mix proportion}

The mix proportion for concrete grade 35 as illustrated in Table 4 which is an approximate mix design in $\mathrm{ACl}$ mix method. Then, the quantity of concrete mixes was calculated by summing up all the volume of specimens with an additional 25 percentage to take care of wastage and shrinkage loss.

The experimental study required 4 batch of concrete mixture for control specimen, $10 \%, 20 \%$ and $30 \%$ of CS replacements. Table 5 shows concrete batching for grade 35 concrete at different percentage replacement of coconut shell. In this investigation, fine aggregate was partially replaced with coconut shell by volume.

\subsection{Experimental tests}

The experimental study required a total of 4 batches of mixture for the concrete mix design. For each batch of mixture, 3 cubes of size $100 \mathrm{~mm}$ were prepared and tested for compressive strength on the 7th, 14th and 28th day, 3 prisms of size $100 \mathrm{~mm} \times 100 \mathrm{~mm} \times 500 \mathrm{~mm}$ were tested for flexural strength at the age of 28 days, 2 cubes of size $100 \mathrm{~mm}$ and 3 cubes of size $150 \mathrm{~mm}$ were prepared for sorptivity and ISAT tests respectively at the age of 28 days for concrete batches of control specimen (0\%) and concrete with $10 \%, 20 \%$ and $30 \%$ of coconut shell as fine aggregate replacement.

\section{Results and discussion}

\subsection{Concrete slump}

Concrete workability is a key property of fresh concrete as it directly or indirectly influences concrete performance in areas of strength, degree of compaction, finishing, reduced concrete bleeding and segregation etc. Results from the workability test showed that concrete slump of all the batch mixes range between values of $28-32 \mathrm{~mm}$. Batches of all concrete mix gave an acceptable concrete slump. The control specimen gave a slump value of $28 \mathrm{~mm}$ while $10 \%, 20 \%$ and $30 \%$ coconut shell fine aggregate replacement gave slump values $29 \mathrm{~mm}, 30 \mathrm{~mm}$ and $32 \mathrm{~mm}$ respectively. The slump of the fresh concrete increase as the percentage of coconut shell replacement increase.

Figure 4 shows an increase in slump height of the concrete corresponding to gradual increment of percentage of coconut shells replacement indicating an increase in workability of the concrete mixture. In a report by Kumar et al. [21] increase in workability of the coconut shell (CS) concretes may be due to particle shape of the coconut

Table 4 Mix proportion for concrete grade 35

\begin{tabular}{lllllll}
\hline Characteristic strength $(\mathrm{MPa})$ & W/C & Water $\left(\mathrm{kg} / \mathrm{m}^{3}\right)$ & Cement $\left(\mathrm{kg} / \mathrm{m}^{3}\right)$ & $\mathrm{FA}\left(\mathrm{kg} / \mathrm{m}^{3}\right)$ & $\mathrm{CA}\left(\mathrm{kg} / \mathrm{m}^{3}\right)$ & C:FA:CA \\
\hline 35 & 0.54 & 215 & 398 & 652 & 1078 & $1: 1.63: 2.71$ \\
\hline
\end{tabular}

Table 5 Concrete batching for grade 35 concrete at various percentage of CS

\begin{tabular}{lllllll}
\hline $\begin{array}{l}\text { Mix } \\
\text { design } \\
(\%)\end{array}$ & $\begin{array}{l}\text { Concrete } \\
\text { volume }\left(\mathrm{m}^{3}\right)\end{array}$ & Cement $(\mathrm{kg})$ & Water $(\mathrm{kg})$ & $\begin{array}{l}\text { Fine aggre- } \\
\text { gate }(\mathrm{kg})\end{array}$ & $\begin{array}{l}\text { Coconut } \\
\text { shell-FA }(\mathrm{kg})\end{array}$ & $\begin{array}{l}\text { Coarse } \\
\text { aggregate } \\
(\mathrm{kg})\end{array}$ \\
\hline 0 & 0.037 & 14.730 & 7.955 & 24.12 & 0 & 39.89 \\
10 & 0.037 & 14.730 & 7.955 & 21.71 & 2.412 & 39.89 \\
20 & 0.037 & 14.730 & 7.955 & 19.30 & 4.824 & 39.89 \\
30 & 0.037 & 14.730 & 7.955 & 16.89 & 7.236 & 39.89 \\
\hline
\end{tabular}




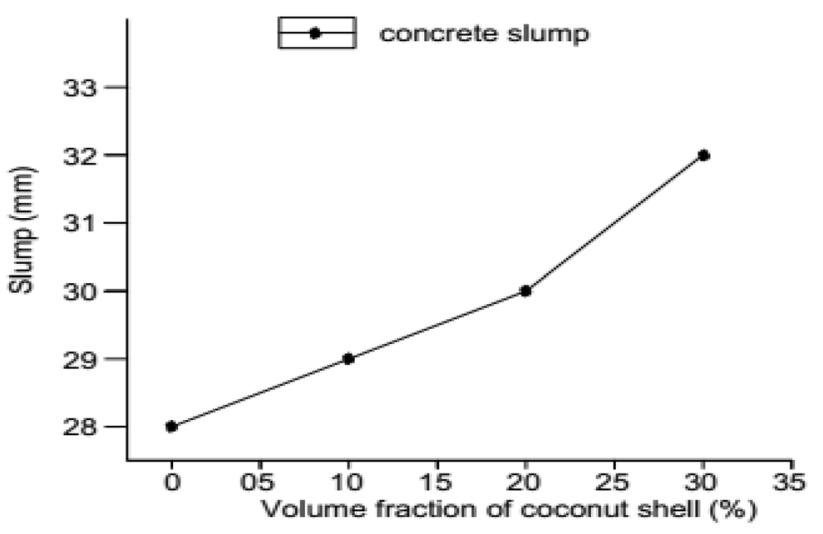

Fig. 4 Concrete slump

shells. In addition, the increase in the quantity of coconut shell also lead to increase in specific surface and also considering the fact that density of sand is much higher than that of coconut shell. Flat shaped CS particles could not have limited the overall movement of the aggregate particles in concrete and thus increase the workability. In conclusion, CS concrete has better workability because of the smooth surface on one side of the shells and the smaller size of coconut shells. Slump values falls within the class limit S1 for true slump as specified in BSEN 12350-2:2009 [22] which makes it suitable for concrete works.

\subsection{Density}

Specific gravity is the major determinant factor of density of concrete as well as other components of concrete. The dead load of a structure can be affected by the density of concrete. A total of 45 cubes were prepared and the densities were evaluated at 7 days, 14 days and 28 days. The average densities of concrete cubes are summarized in Table 6.

From Table 6; the control specimen achieved a maximum density of $2342 \mathrm{~kg} / \mathrm{m}^{3}$, while the $30 \%$ coconut shell fine aggregate replacement gave a minimum density of $2170 \mathrm{~kg} / \mathrm{m}^{3}$ which is still above the density range of lightweight concrete which is $1800-2000 \mathrm{~kg} / \mathrm{m}^{3}$. Notwithstanding, it can be applied in areas where resistance to heavy

Table 6 Density of concrete cubes $\left(\mathrm{kg} / \mathrm{m}^{3}\right)$

\begin{tabular}{lllll}
\hline $\begin{array}{l}\text { Age of testing } \\
\text { (days) }\end{array}$ & \multicolumn{4}{l}{ CS fine aggregate replacement (\%) } \\
\cline { 2 - 5 } & 0 & 10 & 20 & 30 \\
\hline 7 & 2330 & 2281 & 2246 & 2173 \\
14 & 2367 & 2273 & 2218 & 2169 \\
28 & 2327 & 2269 & 2220 & 2170 \\
Average & 2342 & 2274 & 2228 & 2170 \\
\hline
\end{tabular}

loads are expected. An increase in replacement of fine aggregates with coconut shells resulted to reduction in density of the mix because sand is heavier than coconut shell. Decreased density of CS concretes could be attributed to direct consequence of specific gravities of the materials. The specific gravity of CS is 1.33 which is lower than sand 2.64. For the purpose of construction, decreased density considerably reduces the self weight of a structure and allow for handling of larger precast units.

\subsection{Compressive strength}

To determine the effect of replacement of coconut shell as fine aggregates on the compressive strength of concrete, the compressive strength of the plain concrete was compared with the other three concrete batch mixes of different volume fraction of coconut shell aggregates (CSA). The tested concrete cubes at 28th day are shown in Fig. 5. The entire concrete cubes showed normal failure cracks. The failure cracks generated are approximately parallel to the direction of applied load with some cracks formed at an angle to the applied load.

The average compression strength for all batches is summarized in Table 7. The data also has been plotted and presented in Fig. 6.

In all the mixes, compressive strength increased with corresponding increase in age. The control specimen yielded a compressive strength of $45.18 \mathrm{MPa}$ on the 28th day. On the other hand, the $10 \%$ replacement of coconut shell aggregate (CSA) mix achieved $42.7 \mathrm{MPa}, 20 \%$ replacement was $42.0 \mathrm{MPa}$ and $30 \%$ replacement was found to be $41.07 \mathrm{MPa}$. All the CS mix compositions have lower compressive strength compared to control sample. The compressive strength decreased as the percentages of CS replacement increased. The steady rise in compressive strength proves that the coconut shell aggregate does not debilitate once the shell is embedding into concrete.

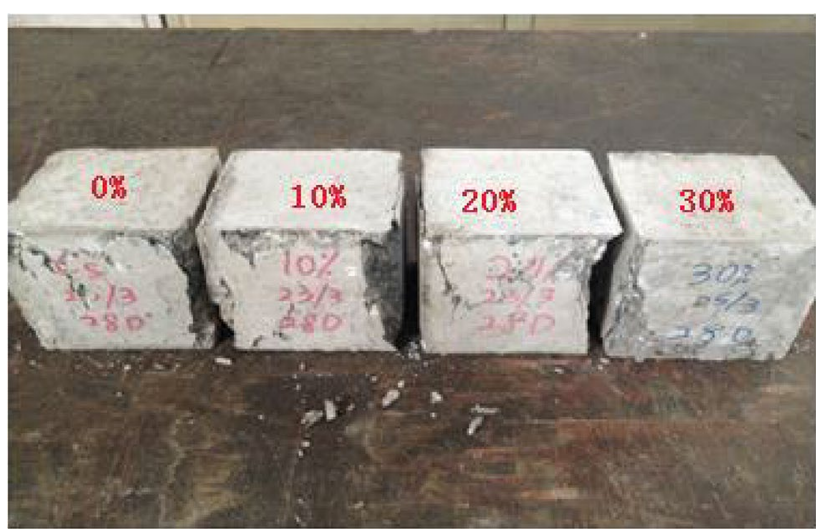

Fig. 5 Tested concrete cubes at 28th day 
Table 7 Compressive strength of concrete with CS replacement (MPa)

\begin{tabular}{lllll}
\hline $\begin{array}{l}\text { CS fine and coarse } \\
\text { aggregate replace- } \\
\text { ment (\%) }\end{array}$ & 7 days & 14 days & 28 days & $\begin{array}{l}\text { Percentages of } \\
\text { final difference }\end{array}$ \\
\hline 0 & 35.03 & 41.74 & 45.18 & - \\
10 & 34.25 & 40.01 & 42.70 & -5.49 \\
20 & 31.63 & 38.58 & 42.00 & -7.04 \\
30 & 30.73 & 34.93 & 41.07 & -9.10 \\
\hline
\end{tabular}

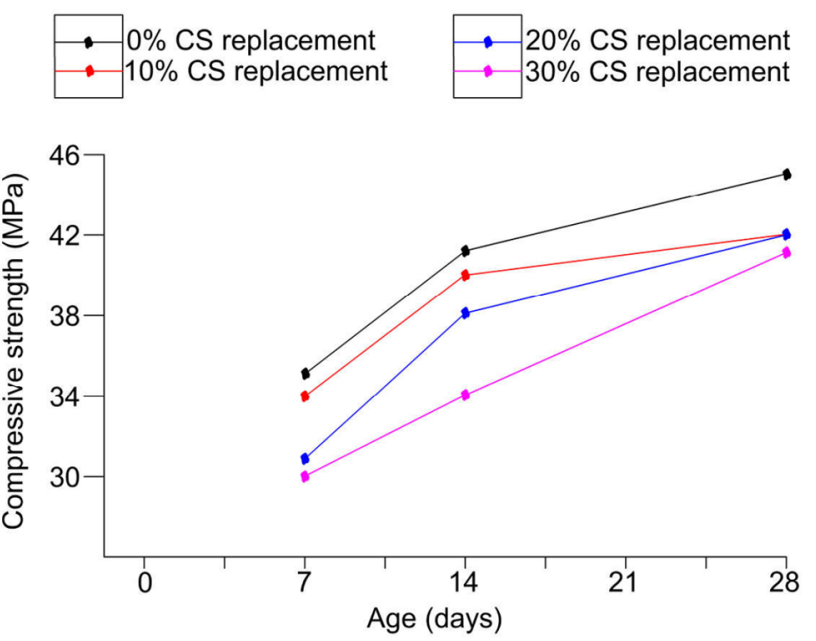

Fig. 6 Development of strength with age

Figure 6 indicates that the control specimen has higher compressive strength as compared to the coconut shell mix compositions. The compressive strength decreased with respect to increase CS percentage replacement. It decreased to $9.1 \%$ compressive strength when the replacement of CSA increased to $30 \%$.

Yerramala and Ramachandrudu [16] observed that bond between aggregate particles is basically determined by the surface texture as better bond is produced between cement paste and particles of rough surface. On the other hand, as a result of the smooth nature of the concave face of the CS aggregates with presence of water will hinder good cohesion amongst the aggregates, which contributed to the lower cohesive strength. Increase in coconut shell replacement gave rise to increase in surface area thereby needing additional cement content for proper bonding. Since the cement content remained the same, the required extra bond was lacking and resulting to reduction of compressive strength. The reduction of compressive strength also can be explained through the mechanical properties of fine aggregate, since coconut shells is weaker than sand, decreasing the quantity of sand and increasing the amount coconut shells in the concrete mix led to decrease in compressive strength [23]. Therefore, 30\% replacement of sand by CS in concrete attained a 28-day compressive strength of $41.07 \mathrm{MPa}$; according to BS 8110 [24] concrete of such strength can be used for structural purposes or high strength lightweight concrete and even a higher percentage replacement can be used for non-load bearing structural elements.

\subsection{Flexural strength}

The control specimen and prisms of CS concrete were tested to evaluate the flexural strength of the concrete at 28th day. The dimensions of the prisms were accurately measured before testing and marked by a marker for placing in the testing machine. The results for flexural strength test are recorded in Table 8.

Table 8 shows that the concrete with three different replacement percentages of CS had lower average flexural strength at 28th day compared to control specimen. Flexural strengths of control specimen and concrete specimens with $10 \%$ CSA, $20 \%$ CSA and $30 \%$ CSA were found to be $3.063 \mathrm{MPa}, 3.045 \mathrm{MPa}, 2.97 \mathrm{MPa}$ and $2.912 \mathrm{MPa}$ respectively. The flexural strength recorded a slight decrease between the control specimen and 30\% CS replacement with $1.97 \%$. Generally, all the CS concretes had flexural strength performance similar to that of the control specimen. Gunasekaran et al. [25] stated that the concretes with conventional aggregates and CS aggregates had the failure in tension occurred as a result of the fracture of the concrete matrix by itself or the breaking of bond between the matrix and the surface of the aggregate used. Implying the surface properties of coconut shells also play an important role in determining the flexural properties of concrete. Even though CS aggregates are more liable to fracture as compared to the conventional aggregates, when the sizes of the shells are reduced, the ability to be fractured will probably decrease. Therefore, the concrete with replacement of CS as fine aggregate possess fracture ability almost equivalent to the control specimen.

Table 8 Flexural strength at 28th day

\begin{tabular}{lll}
\hline $\begin{array}{l}\text { Percentage of CS replace- } \\
\text { ment (\%) }\end{array}$ & $\begin{array}{l}\text { Modulus of rupture } \\
(\mathrm{MPa})\end{array}$ & $\begin{array}{l}\text { Percentage of } \\
\text { difference (\%) }\end{array}$ \\
\hline 0 (control specimen) & 3.063 & - \\
10 & 3.045 & -0.588 \\
20 & 2.970 & -2.439 \\
30 & 2.912 & -1.970 \\
\hline
\end{tabular}


Table 9 Sorptivity of concrete with different CS replacement

\begin{tabular}{lll}
\hline Specimen & $\begin{array}{l}\text { Average initial } \\
\text { absorption }(\mathrm{mm} / \\
\left.\mathrm{s}^{0.5}\right)\end{array}$ & $\begin{array}{l}\text { Average secondary } \\
\text { absorption }\left(\mathrm{mm} / \mathrm{s}^{0.5}\right)\end{array}$ \\
\hline 0 (control specimen) & 0.0166 & 0.0098 \\
10 & 0.0188 & 0.00975 \\
20 & 0.0173 & 0.0094 \\
30 & 0.0172 & 0.0087 \\
\hline
\end{tabular}

\subsection{Sorptivity}

The degree of porosity of a concrete structure is determined by its sorptivity. Higher sorptivity indicates lower resistance of the concrete towards absorption of water. The rate of durability of a concrete structure can also be determined by the level of sorptivity of the concrete structure, if the sorptivity rate is high then the durability of the concrete will be low. The results of sorptivity for all concrete mixes are tabulated in Table 9.

The initial rate of absorption for the tested concretes ranged between 0.0166 and $0.0188 \mathrm{~mm} / \mathrm{s}^{0.5}$. From the result obtained, the lowest initial absorption was the control concrete which was $0.0166 \mathrm{~mm} / \mathrm{s}^{0.5}$ and the highest initial absorption was $10 \%$ CS concrete with $0.0188 \mathrm{~mm} /$ $s^{0.5}$.

In the case of the secondary absorption the value ranged between 0.0087 and $0.0098 \mathrm{~mm} / \mathrm{s}^{0.5}$ which are lower than the initial absorption. Plain concrete exhibited the highest value of $0.0098 \mathrm{~mm} / \mathrm{s}^{0.5}$, while $30 \% \mathrm{CS}$ concrete showed lowest with value of $0.0087 \mathrm{~mm} / \mathrm{s}^{0.5}$. This means that CS concretes had a higher rate of absorption at the earlier stage of experiment compared to control specimen, it happened as a result of the high effective porosity at the initial absorption as compared to the low effective porosity at the secondary absorption.

In a report by Yerramala and Ramachandrudu [16] volume of concrete paste matrix influences the sorptivity of concrete, the zone of interfacial contact around the aggregate particles and the pore structure of the bulk matrix. It was observed that the coconut shells with curved shape, elongated shape and lack of bond between the aggregate particles and paste gave rise to more porous structure thereby giving the coconut shell concrete higher absorption values compared to the control specimen. Hence, the CS replacement in concrete will increased the sorptivity of concrete. The non uniformity trend of initial absorption of concrete may be attributed to the improper vibration of concrete during mixing and also difficulty in compacting the CS concrete into a compact whole as a result of the smooth slippery surface on the concave face of the CS. Improper vibration will lead to formation of pores in the concrete specimens; thereby causing concrete to exhibit higher sorptivity.

\subsection{Initial surface absorption test (ISAT)}

Initial surface absorption (ISAT) test is almost similar to the sorptivity test, the different is that for ISAT water is introduced into the concrete from the top using an applied pressure of $200 \mathrm{~mm}$ head and allowed to penetrate the pores under gravity, whereas for sorptivity test water penetrates into the concrete pores through capillary action (upward movement of water). This test is of great importance for concrete quality as concrete structure need to be impermeable to provide better resistance to water absorption and reducing the risk of corrosion of reinforcements. Table 10 shows the result obtained from the ISAT experiment respect to different specimens.

Table 10 shows the ISAT results at different percentages of CS replacement. The rate of absorption of the specimens increased uniformly with the addition of CS replacement from 0 to $30 \%$ for absorption at $10 \mathrm{~min}$ and $60 \mathrm{~min}$ respectively. For the $30 \%$ CS replacement concrete, the value decreased from 0.8420 to $0.3550 \mathrm{ml} / \mathrm{m}^{2} \mathrm{~s}$ for $10 \mathrm{~min}$ and $60 \mathrm{~min}$ respectively. However, it showed a highest value compared to other concretes mixes. The absorption at $10 \mathrm{~min}$ was higher than $60 \mathrm{~min}$ because the absorption capacity of concrete depends on effective porosity. At $60 \mathrm{~min}$, the pores of concrete are mostly likely filled with water.

As recorded in the sorptivity test coconut shell concrete showed higher value when CS replacement increased, this result shows that water absorption capacity of the CS is $6.17 \%$ high as compared to $3 \%$ fine aggregate (sand) absorption, it can be concluded that the shells absorbed very little amount of water when ISAT test was carried out. The moisture retaining and water absorbing capacity of coconut shell aggregates are higher than conventional aggregates. The porosity of a concrete structure determines the strength and water absorption capacity of the concrete even as the two factors are in opposite relationship to one another i.e. increase in porosity results to increase in water absorption and decrease in strength of the concrete [26].

Table 10 Initial surface absorption test (ISAT)

\begin{tabular}{llll}
\hline Sample (\%) & \multicolumn{3}{l}{ Initial surface absorption test $\left(\mathrm{ml} / \mathrm{m}^{2} \mathrm{~s}\right)$} \\
\cline { 2 - 4 } & $10 \mathrm{~min}$ & $30 \mathrm{~min}$ & $60 \mathrm{~min}$ \\
\hline 0 (control specimen) & 0.7665 & 0.5213 & 0.2521 \\
10 & 0.7871 & 0.5196 & 0.2675 \\
20 & 0.8025 & 0.5402 & 0.3001 \\
30 & 0.8420 & 0.5779 & 0.3550 \\
\hline
\end{tabular}


Table 11 Cost analysis of concrete mixes

\begin{tabular}{llll}
\hline $\begin{array}{l}\text { Replacement of } \\
\text { fine aggregate (\%) }\end{array}$ & $\begin{array}{l}\text { Material cost of 1 } \\
\text { cubic concrete }(\$)\end{array}$ & $\begin{array}{l}\text { Reduction } \\
\text { of cost }(\$)\end{array}$ & $\begin{array}{l}\text { Reduction } \\
\text { of cost (\%) }\end{array}$ \\
\hline Control specimen & 68.44 & - & - \\
10 & 67.10 & 1.33 & 1.96 \\
20 & 65.77 & 2.67 & 3.91 \\
30 & 64.44 & 4.00 & 5.87 \\
\hline
\end{tabular}

\subsection{Cost analysis}

Cost analysis was carried and compared with each concrete mix design. It was assumed that the cost of labor and cost of other facility requirements are same for both conventional concrete and CS aggregate based concrete. Therefore, these cost components were not considered in this analysis. Quantity of the material was determined according to mix proportions. Amount of cement, sand and CS were quantified weight basis. With these prices and material quantities, the material cost of one cubic meter concrete was determined and compared with the material cost of a control concrete. No cost was considered for coconut shells since they are freely available. The cost to produce the concrete decreased with the increased of CS replacement. Table 11 below is a summary of the cost analysis for different concrete type according to replacement of CS as fine aggregate.

The cost in the production of concrete by $30 \%$ replacements of CS as fine aggregates gave a reduction of 5.87\% compared to the control specimen concrete. The utilizing of coconut shell as aggregate in concrete can produce low cost building materials in the construction industry. In addition, the use of CS in concrete is acceptable, because the structural strength of CS concrete is comparable to conventional concrete in the difference within the range of $10 \%$.

Maninder and Manpreet [27] showed that there is a cost reduction of $30 \%$ and $42 \%$ respectively for concrete produced of mix ratios (1:1:2) and (1:2:4) from coconut shell and palm kernel shell respectively. Hence, it is of the essence to encourage housing developers to investing these materials for construction purposes.

\section{Conclusions}

At the end of the study the following conclusions are made:

- Addition of CS increases the workability of concrete. The slump increased to $32 \mathrm{~mm}$ when the CS replacement increased to $30 \%$.
- Increase of CS replacement percentage decrease the densities of the concretes. 30\% of CS replacement showed density $2170 \mathrm{~kg} / \mathrm{m}^{3}$.

- Inclusion of CS in concrete reducesthe compressive strength of concrete. For inclusion of $30 \%$ volume of CS aggregate fraction in concrete give compressive strength of $41.07 \mathrm{MPa}$, which is a drop of $9.10 \%$ as compare to the control specimen. However, concrete with CS replacement up to $30 \%$ can still be consider as structural concrete as it is more than $30 \mathrm{MPa}$. Therefore, it can be used for structural purposes.

- The flexural strength of volume fraction of 0 to $30 \%$ coconut shell replacement concrete decreased from 3.063 to $2.912 \mathrm{MPa}$ with the dropped of $1.97 \%$.

- For the sorptivity test, initial absorption of control concrete have lowest than all CS concrete, while the secondary absorption of it showed the highest value. Similar to the sorptivity, ISAT test shows that the concrete present higher absorption behavior when the replacement of CS increase.

- The cost to produce concrete reduce to $5.87 \%$ with the increase of $30 \%$ CS replacement as fine aggregate when compare to the control specimen.

\section{Compliance with ethical standards}

Conflict of interest The authors declare that they have no conflict of interest.

\section{References}

1. Alengaram UJ, Muhit BAA, Jumaat MZB (2013) Utilization of oil palm shell as lightweight aggregate in concrete-a review. Constr Build Mater 38:161-172. https://doi.org/10.1016/j.conbu ildmat.2012.08.026

2. Reddy BD, Jyothy SA, Shaik F (2014) Experimental analysis of the use of coconut shell as coarse aggregate. IOSR J Mech Civ Eng 10(6):06-13

3. Olanipekum EA, Olusola KO, Ata O (2006) A comparative study of concrete properties using coconut shell and palm kernel shell as coarse aggregates. J Build Environ 41(3):297-301. https://doi. org/10.1016/j.buildenv.2005.01.029

4. Gunasekaran K (2008) Lightweight concrete using coconut shells as aggregate. In: Proceedings of international conference on advances in concrete and construction, ICACC, Hyderabad, 2008, India, pp 450-59

5. Muthusamy K, Sabri NA (2012) Cockle shell: a potential partial coarse aggregate replacement in concrete. Int J Sci Environ Technol 1(4):260-267

6. Falade $F$ (1995) An investigation of periwinkle shells as coarse aggregate in concrete. J Build Environ 30(4):573-577. https:// doi.org/10.1016/0360-1323(94)00057-Y 
7. Adefemi A, Nensok MH, Kaase ET, Wuna IA (2013) Exploratory study of date seed as coarse aggregate in concrete production. Civ Environ Res 3(1):85-92

8. Muthusamy K, Nordin N, Vesuvapateran G, Ali M, Annual NAM, Harun $\mathrm{H}$ et al (2014) Exploratory study of rubber seed shell as partial coarse aggregate replacement in concrete. Res J Appl Sci Eng Technol 7(6):1013-1016

9. Pinto J, Vieira B, Pereira H, Jacinto C, Vilela P, Paiva A et al (2012) Corn cob lightweight concrete for non-structural applications. Constr Build Mater 34:346-351

10. Emiero C, Oyedepo OJ (2012) An investigation on the strength and workability of concrete using oil palm shell and palm kernel fibre as a coarse aggregate. Int J Sci Eng Res 3(4):1-5

11. Salas J, Alvarez M, Veras J (1986) Lightweight insulating concretes with rice husk. Int J Cem Compos Lightweight Concr $8(3): 171-180$

12. Shafigh $P$, Jumaat $M Z$, Mahmud $H$ (2011) Oil palm shell as a lightweight aggregate for production high strength lightweight concrete. Constr Build Mater 25(4):1848-1853. https:// doi.org/10.1016/j.conbuildmat.2010.11.075

13. Shafigh $P$, Jumaat $M Z$, Mahmud $H$, Norjidah AA (2012) Lightweight concrete made from crushed oil palm shell: tensile strength and effect of initial curing on compressive strength. Constr Build Mater 27(1):252-258. https://doi.org/10.1016/j. conbuildmat.2011.07.051

14. Shafigh $P$, Mahmud HB, Jumaat MZ (2012) Oil palm shell lightweight concrete as a ductile material. Mater Des 36:650-654. https://doi.org/10.1016/j.matdes.2011.12.003

15. Gunasekaran K, Annadurai R, Kumar PS (2012) Long term study on compressive and bond strength of coconut shell aggregate concrete. Constr Build Mater 28(1):208-215. https://doi. org/10.1016/j.conbuildmat.2011.08.072

16. Yerramala A, Ramachandrudu C (2012) Properties of concrete with coconutshells as aggregate replacement. Int J Eng Invent 1(6):21-31

17. Department of Agriculture Malaysia (2012) Coconut shell production in Malaysia. http://agrolink.moa.my. 5 Oct 2015
18. BS EN 197-1:2000 - Cement. Composition, specifications and conformity criteria for common cements. British standard institution, London

19. ASTM C136-06 (2006) Standard test method for sieve analysis of fine and coarse aggregates. Annual book of American society for testing and materials standards. West Coshohocken

20. ASTM C33-03 (2003) Standard specification for concrete aggregates. Annual book of American society for testing and materials standards. West Coshohocken

21. Kumar KM, Kumar VRP, Gunasekaran K (2016) Study on mechanical properties of high-performance concrete using coconut shell as coarse aggregate. Int J Chem Sci 14(S1):247-256

22. BS EN 1235-2:2009 - Testing fresh concrete. Slump test. British standard institution, London

23. Daniel YO (2013) Experimental assessment on coconut shell as aggregate in concrete. Int J Eng Sci Invent 2(5):07-11

24. BS 8110: Part 1 (1997) Structural use of concrete. Code of practice for design and construction. British Standards Institution, London

25. Gunasekaran K, Kumar PS, Lakshmipathy M (2011) Mechanical and bond properties of coconut shell concrete. Constr Build Mater 25(1):92-98. https://doi.org/10.1016/j.conbuildma t.2010.06.053

26. Gunasekaran K, Annadurai R, Kumar PS (2015) A study on some durability properties of coconut shell aggregate concrete. Mater Struct 48(5):1253-1264. https://doi.org/10.1617/s1152 7-013-0230-2

27. Maninder K, Manpreet K (2012) A review on utilization of coconut shells as coarse aggregate in mass concrete. Int J Appl Eng Res 7(11):1-2

Publisher's Note Springer Nature remains neutral with regard to jurisdictional claims in published maps and institutional affiliations. 